\title{
Perceptions And Validation Of Key Information Technology Competencies From An IT Alumni Viewpoint: Another Stakeholder In The Curriculum Design Process
}

\author{
C. Steven Hunt, Morehead State University, USA \\ Tena B. Crews, University of South Carolina, USA \\ Susan Feather-Gannon, Pace University, USA \\ Darla Hunt, Maysville Community \& Technical College, USA \\ Lola B. Smith, Morehead State University, USA
}

\begin{abstract}
The objective of this research was to determine the perceptions of End-user Information Systems graduates from selected universities (now alumni status) regarding an updated Organizational \& End-user Information Systems (OEIS) curriculum sponsored by the Organizational Systems Research Association now referred to as AIS-SIG OSRA. The study included the following research objectives: (1) to determine the perceived level of importance of the OEIS curriculum content in today's global workforce and (2) to ascertain the information systems (IS) personnel viewpoints on the overall importance of the specific course objectives. Survey findings revealed specific topics are of critical and/or considerable importance upon graduation from an end-user information systems-related program. An understanding of the systems development life cycle (SDLC) including planning and implementation of end-user support systems in combination with troubleshooting skills were perceived to be noted essential components of an IT curriculum. Moreover, an experiential learning/internship experience-similar to a clinical practicum--was deemed to be of critical importance for information technology (IT) professionals. To further validate the model, it is recommended that universities in other regions of the United States survey their alumni to assess what specific IS \& IT objectives and skill sets are currently needed, especially given the exponential demand for trained personnel in emerging areas of health information technology, enterprise systems, project management, virtualization, and information assurance.
\end{abstract}

Keywords: end-user Information Systems; information technology curricula; systems perspective; business information systems; Organizational Systems Research Association (OSRA) Model Curriculum

\section{INTRODUCTION AND PROBLEM}

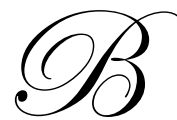

usiness transformation, changing digital-commerce markets, enterprise-wide initiatives, as well as emerging business applications at the desktop level in organizations, have continued to place pressure on organizational and end-user information systems (OEIS) and IT undergraduate programs to undertake frequent curriculum renovations given the dynamic nature of the discipline. The Organizational Systems Research Association (now AIS-SIG OSRA) recognized this need a few years ago, and appointed a group of international OEIS scholars and IT practitioners to redesign a Model Curriculum in Organizational \& End-User Information Systems education for undergraduates. However, to further validate and solidify the importance of 
specific IT competencies, more evaluation and survey analysis of different stakeholders was deemed paramount to assist academicians in future curriculum reengineering efforts. Moreover, with exception of educator feedback, an inadequate research knowledge base was lacking regarding the curriculum's objectives as perceived by IT alumni graduates - a critical stakeholder with vested interests.

\section{RESEARCH QUESTIONS}

The research study sought responses to the following research questions:

1. What is the perceived level of importance of the OEIS curriculum content in today's global workforce and

2. What are alumni-currently working in IT positions--perceptions and viewpoints on the overall importance of the specific course objectives as well as those competencies deemed to be of critical and/or considerable importance upon graduation from an end-user information systems-related program.

\section{REVIEW OF THE LITERATURE}

\section{The Need for IT Workers and Updating IT Curricula}

By the end of 2007, our nation's high-tech deficit reached "new record highs, measured either in absolute terms or as a share of the overall trade deficit" (Weller \& Wheeler, 2008). While the Global Competitiveness Report 2008-2009 noted the U.S. still tops the overall ranking, it also indicated that Denmark, Sweden and Switzerland now lead the most networked economies (World Economic Forum, 2009). The Global Information Technology Report of 2007-2008 also remarked that the U.S. currently does not lead a single category included in the report, such as Business Readiness, Business Usage, or Individual Readiness, etc.(World Economic Forum, 2008). It appears that "while other countries have been investing in innovation policies to create a skilled workforce so as to improve their global competitiveness, the U.S. has, by and large, neglected to make innovation a policy priority," (Weller \& Wheeler, 2008).

The Rand Study (2008) on the other hand was a bit more optimistic, indicating that the U.S. still remains the dominant leader in science and technology worldwide. Nonetheless, the Rand Study also acknowledged this leadership is a direct result of the benefits derived from foreign scientists and engineers. As such, "The United States cannot afford to be complacent. Effort is needed to make sure the nation maintains or even extends its standing," (p.1).

As observed by Abu-Hamatteh and Al-Jufout (2003) the "backbone of any industry is always presented by the quality of the educational establishments' outcomes, which therefore enhances the world economy." Given the need for foreign workers to maintain U.S. competitiveness, there is a growing concern about the deficit of skilled U.S. Information Technology (IT) workers and how it will inhibit the profitability and productivity of U.S. corporations (NACE, 2008). Ironically, at a time when the demand for people with Information Systems (IS) and IT skills is at an all-time high, the number of IS and computer science students (over the past several years) has taken a nose dive (Caputo, 2005; Klawe, 2005; Snyder, Slauson, \& Capenter, 2009). This downturn could negatively impact the future of the profession and negatively impact business in the $21^{\text {st }}$ century.

This is disconcerting when one considers that joblessness among American IT workers averaged 2.1 percent in 2008, down from 2.5 in 2006 (Chabrow, 2008). Furthermore, a recent Employment Dynamics and Growth Expectations report shows that demand for technology skills will significantly increase in the coming months as the pace of hiring begins to accelerate in this sector (Ballenstedt, 2009). For example, federal agencies will need to hire more than 11,000 IT pros, according to a survey released by the Partnership for Public Service (Jackson, 2009).

Given the current need for greater hiring in the IS field and a low IT unemployment rate of 2.1 percent, which many economists considers full employment, the following argument bolstered by many Corporate Information Officers continues to be forwarded: As it is difficult to find qualified IS \& IT professionals, many American companies have now considered outsourcing overseas to fill such openings and/or considered bringing 
foreign workers to the United States on H-1B visas (Kantor, 2005; Kurtz, 2008; NACE, 2008). To emphasize this, Sparrow (2003) notes that technological changes are rapid and paralleled by changes in the way IT is managed and viewed by different organizations.

Obviously, this situation or risk of becoming a technological backwater must be addressed. What's ultimately at stake, according to former Labor Secretary Robert Reich, now a professor at UC Berkeley, is continued leadership, dominance, or in some cases the survival of information businesses. Gordon (2005), author of The 2010 Meltdown: Solving the Impending Jobs Crisis, notes the forthcoming IT workforce shortage is a legitimate area of concern. Gordon suggests millions of Americans do not have the appropriate talent for the jobs that need to be filled - highly skilled positions requiring specialized technology training and education.

Plas (2008) noted in 2010, a tsunami of 79 million Baby Boomers will begin to leave the workforce and approximately 60 percent of the jobs which must be filled now are occupied by Baby Boomers that will need to be replaced. Many Boomers have the technical skills to keep the economy running, and they represent a larger cadre of people with more technical skills than the generations behind them. Kao (2007) in Innovation Nation notes, "The strength of America is in the population that's closest to retirement, while the strength of many countries against whom we compare ourselves is their younger population," (p. 33).

According to Murphy (2007), the total IT employment outlook is better than the past seven years, especially for IT managers and network systems analysts. A 2008 U.S. News Report indicated computer systems analyst/architect/designers as being among the best career choices in terms of the most stable employers (i.e. government agencies and universities). Overall, according to data compiled by the Association for Information Systems (Galletta, 2007), there is growth in the technology job market - by 2014, 1 out of every 4 jobs will involve the use of computer-related technology.

Because technology underpins everything from ATMs to fighter jets, according to Hudson Institute researcher, Haley Glover, "Computer and data-processing fields alone are likely to produce nearly 1 million jobs by 2010," (Meyers, 2010). Anyone looking for a job in today's economy needs to consider highly skilled employment opportunities that demand complex skills. In other words, there is and has been an increasing demand from corporations for deep industry expertise from people who have a thorough grasp of arcane and complex technology and business related processes. In this regard, IT Service Management is an emerging discipline to enhance existing academic IT program offerings. The IT Service Management Forum conducted a survey which shows there is a market of at least 15,000 hires per year in the U.S. who have IT Service Management skills (Conger, Venkataraman, Hernandez, \& Probst, 2009).

Hopkins, Vice President of Skills Development at the Computing Technology Industry Association (CompTIA) (2008) notes "there is a distinct shortage of certain IT skills, and that shortage seems to be growing" (referenced by Hoffman, 2008, para. 2). Clearly, the need for IT workers is growing and in demand, but the identification of the specific skills required for the wide variety of positions in the past has not been as clear. However, Hoffman (2008) notes the following as essential skills: programming/application development; project management; help desk/technical support; security; data centers; business knowledge; and networking and telecommunications. However, management Information Systems (MIS) managers are challenged by trying to find competent workers for open positions. The proliferation of the Internet, security, data growth, and data management also poses challenges for MIS managers. This challenge is augmented by the constant change in information systems.

During stressful economic times, managers, facing tough budgetary pressure, are forced to examine more thoroughly what knowledge and skills are needed to survive. Galup, Dattero and Quan (2004) investigated the desired IT knowledge and skills employers are searching for in these turbulent times through the content of current job advertisements. The study conducted by Galup, Dattero, and Quan identified changes in demand for knowledge and skills in hardware, software, and development methodologies. This exploratory investigation on desired IT skills suggests the trend toward Web services is strong. Moreover, the study revealed a decrease in the demand for hardware knowledge, and weak demand in traditional second and third generation programming languages and an increased demand for software knowledge especially related to web based technologies. 
This identified increase in demand for software knowledge and skills (i.e. ERP skills) is also supported by the 2008 U.S. Bureau of Labor Statistics report that states that of the 10 job classifications in greatest demand for the next 10 years, four are IT related - specifically, application computer software engineer, systems software, network analysts, and data communication specialists. The implications for management are far reaching as they (1) search and recruit new hires as well as retrain and retool IT professionals over the next decade and (2) replace legacy systems with older technology with new systems based on web technology.

It is essential curricula reflect the needs of an ever-changing environment to provide competent IT workers. Miller \& Dettori (2008) researched IT knowledge, skills and competencies needed for IT careers by interviewing IT professionals. The findings indicated that a specific programming language or platform was not noted as relevant; object-based user interface development was useful for specific positions; the ability to model and distinguish between interface and the implementation of such interface was essential; and the use of hypothetical scenarios to observe a student's problem processing was a commonly used process. Therefore, preparing students to become competent IT employees with well-rounded skills is a goal of post-secondary departments with an end-user support system focus. The demand for well-prepared IT professionals is the driving force behind these changes in business and economic growth. Additionally, "Computer support specialists and systems administrators are projected to be among the fastest growing occupations over the 2002-12 period" and experts predict an increase of 35.8 percent during this time period (Occupational Outlook Handbook, 2004-2005).

Academia faces the difficult task of providing up-to-date curricula in a constantly changing environment. This emphasizes the need for educational institutions to bridge the gap and produce qualified graduates who will become eligible applicants for the available positions in the IT world. Additionally, those responsible for teaching key courses in the area of end-user information systems (EUIS) must ensure the proper curriculum is available to produce graduates equipped with the essential skills necessary to advance in the job market or to a higher level of education.

Therefore, post-secondary institutions are charged with the responsibility to educate students to become highly-skilled employees in the IT field. Universities cannot sit idle while technology, and eventually students, pass them by for more applicable curricula to help them become the knowledge workers of tomorrow. Moreover, "A model curriculum provides a basis for evaluating both a school's curriculum and a school's use of, and need for, resources" (Dwyer \& Knapp, 2004, p. 410).

As noted by Crews (2004) "Those responsible for teaching key courses in the area of information technology must ensure that the curriculum and courses result in the achievement of the critical skills necessary to advance in the job market or in the advancement of education" (p. 419). However, no one individual skill will make students competent for the IT workforce. A combination of these skills will help provide students with the necessary aptitude to gain a competitive advantage in IT-related occupations. Continued development in ecommerce, wireless networks, and further advances in technology will also increase the need to update skills in IT fields.

Lee (2005) examined skill requirements of systems analysts in Fortune 500 organizations. From the analysis of the data obtained from the respondents, this research further solidifies the significance of core business knowledge to systems analysts because they often become blended into the business processes of the firm. Moreover, the findings revealed a significant number of companies require their analysts to have a general understanding of the Internet. The results also indicated it is necessary for systems analysts to possess both behavioral and technical skills. In short, it can be argued analysts need soft, behavioral skills, as much as hard, technical skills. More specifically, Lee noted specific content areas that are most likely to be in demand are database, functional business knowledge, communication skills, interpersonal skills, and all phases of the IT development cycle which has often been a key element of the OEIS Model Curriculum.

Technology advancements force academicians and prospective IT employers to look toward new trends and issues in the area of IT and end-user computing. For example, security is an important element and will continue to increase in importance exponentially. Network security and password encryption have gained increased attention as businesses and educational institutions install wireless networks. Crews (2005) noted in a study of educators and 
industry IT personnel that much more emphasis is being placed on securing a network. In the 2005 Delphi study, the main topic of securing a network reached consensus because all participants rated this topic as one of the topics to definitely include in a telecommunications course at the college/university level. Three of the defined subtopics under the securing a network topic also reached consensus. This finding emphasizes the need for security to be included in an OEIS-related curriculum. Due to the access to data and the flaws in network topologies, improved security is critical. Network administrators are continually learning how to update, maintain, and protect their data, users, and investment in telecommunications environments with or without wires.

The IT environment consists of a wide variety of technological challenges to prepare IT graduates. However, according to Crews (2004), keeping up with an ever-changing information technology environment is a challenge for academicians as well. Therefore, to prepare IT students for the work world, obtaining input from professionals in the field is essential.

\section{Important End-User Information Systems Skills}

Forecasts reveal businesses which will dominate the global economy of the future will be information, technology, or knowledge-based organizations. Consequently, the emerging information technologies are also requiring a new breed of IT professional - a person who understands the needs of the business as well as IT and its potential for enhancing productivity at the desktop. These skills are essential to prepare students for growing IT professional. As noted by the Bureau of Labor Statistics (2008), jobs in the area of computer software engineers are projected to increase 38\% between 2006 and 2016. Others noted in the handbook are computer support specialist (increasing 13\%); systems administrators (increasing 27\%); and computer systems analysts (increasing 29\%) over the period between 2006 and 2016.

Yellen (2005) examines two features of end-users in organizations learning to use systems and software (S\&S) implemented in this organization. The research does not arrive at strong conclusions but rather asks questions from the literature that need to be addressed before any new technology is introduced in large numbers in today's workplace. The importance of end-user involvement in the process of learning to use new software is well documented, and a recurring theme in these studies is the importance of the human factor. This shortcoming can be partially attributed to the rapid growth of technology coupled with the increasing use of IT by end-users who may not be particularly computer literate. Yellen also notes the unfortunate issue about this well-documented and recurring conclusion concerning the importance of end-user training is that the literature also strongly suggests the problem is not being solved and efforts to address the issue are being ignored. The study findings suggest inadequate end-user training is a large and growing financial expense for the organization and the best one could hope for is that small incremental improvements will be made in the way instruction is delivered. Since IT technologists are known as problem solvers, vigorous efforts must be made to solve, or at least reduce, the problem.

Many people believe prospective employees cannot be competitive in the IT market unless programming is an essential component of their repertoire, However, the data provided in the Occupational Outlook Handbook 2008-2009 Edition (2008) indicates computer programming positions will slightly decrease between 2006-2016 by 4 percent. Notwithstanding, technology-related careers were predicted to be among the 10 fastest-growing occupations through 2010 (Kaihla, 2003). The Bureau of Labor Statics (2008) provide evidence that employment in professional, scientific, and technical services will continue to grow by approximately $30 \%$ by 2016 which will add over two million new opportunities for employment. The OEIS curriculum prepares undergraduates who bridge the gap between the developer of IT and the typical computer end-user. This area of concentration also gives emphasis to understanding how IT contributes to individual and work group performance. Programs in OEIS often equip students for non-programming-related job opportunities and specifically for entry-level career titles, such as: software trainer, PC support specialist, technology coordinator, Web designer, help desk administrator, network analyst, and other mid-level positions, such as process improvement manager or director of online learning. The updated OEIS curriculum includes courses that allow IT students to study and work in all career titles mentioned above.

To further complement the importance of the OEIS Model, Smith, Hunt, Berry and Hunt (2005) developed the Management, Technology, and Communication (MTC) triad baseline model for training knowledge workers in a 
digital economy. This model reinforces the essential objectives and recommended competencies housed in the OSRA's 2004 OEIS Model Curriculum. The MTC baseline represents a learning environment wherein the ultimate objective is to provide OEIS students with systemic skills so they know how to manage, communicate, and implement effective technological solutions in a global marketplace. One may enter the model from any direction, and one can easily move to any other component without leaving the structure. Such an organic interconnected model reflects a college/university setting where OEIS students, may be simultaneously engaged in different courses in diverse departments. The authors establish a strong case of the need for an organizational environment where hard skills are paired with soft skills, where qualitative research is seen as having as much intrinsic value as quantitative research, where creative thinking along with critical thinking should be encouraged in an IT program. This is solidified as well by Xie \& Bahaudin (2008), in noting job seekers in the twenty-first century workplace will need not only the technical skills, but also soft skills such as communication skills, interpersonal skills, team player dynamics, responsibility and creativity skill sets.

Moreover, Ragan (2007) further noted the importance of interdisciplinary skills — as an emerging trait in high demand especially as ERP systems become commonplace in today's global economy. This emphasis could seamlessly be offered as a track or specialty in an IT area of concentration so business students may acquire more educational opportunities in business process improvement, supply chain management, and customer relationship management - all of which are critical factors in today's corporate infrastructure.

\section{RESEARCH DESIGN}

\section{The Sample}

Participants in the study represented a selected group of alumni from universities in the Midwest and southern regions of the United States. A letter explaining the Web-based survey project was emailed to 117 participants. Forty (34\%) alumni responded during the four weeks following the initial email contact.

The objectives of the courses in the OEIS curriculum model served as the basis for the instrument developed to seek alumni opinions regarding the curriculum. Examples of objectives include: 1) assign users to groups and ensure adequate permissions on the network and 2) recognize and apply appropriate web design to meet user requirements. The complete list of objectives is displayed in Table 1 with mean, standard deviation and $\mathrm{N}$ value.

Table 1: Alumni Ratings of Curriculum Objectives - Summary List

\begin{tabular}{|c|c|c|c|}
\hline Components/Objectives of the Curriculum & Mean & $\begin{array}{l}\text { Std } \\
\text { Dev }\end{array}$ & $\begin{array}{c}\mathbf{N} \\
\text { Value }\end{array}$ \\
\hline $\begin{array}{l}\text { Demonstrate readiness for employment for an entry-level IT related position through } \\
\text { completion of an IT internship. }\end{array}$ & 4.6 & 1.0 & 40 \\
\hline Assess user needs and recommend computer solutions. & 4.4 & 0.6 & 40 \\
\hline Set up perform disk, directory, and file backups. & 4.4 & 0.9 & 39 \\
\hline Install, configure, upgrade, and maintain software. & 4.4 & 0.9 & 40 \\
\hline Demonstrate an understanding of software system maintenance and troubleshooting. & 4.3 & 0.9 & 39 \\
\hline $\begin{array}{l}\text { Understand and apply the concepts and theories underlying the administration of information } \\
\text { systems security. }\end{array}$ & 4.3 & 0.8 & 39 \\
\hline Implement, monitor, and troubleshoot basic information, network, and Web security systems. & 4.2 & 0.8 & 38 \\
\hline $\begin{array}{l}\text { Describe characteristics of end-user work environments and the impact of information } \\
\text { technology on work performance. }\end{array}$ & 4.2 & 0.9 & 40 \\
\hline Identify project objectives and end-user requirements. & 4.2 & 0.7 & 40 \\
\hline Design cost-effective technical training including new training and upgraded training. & 4.2 & 1.0 & 40 \\
\hline $\begin{array}{l}\text { Identify organizational and management issues related to the use of technology in the } \\
\text { workplace. }\end{array}$ & 4.2 & 1.0 & 40 \\
\hline Setup, install, configure and troubleshoot hardware. & 4.2 & 0.9 & 40 \\
\hline $\begin{array}{l}\text { Describe the concept of end-user technology support and differentiate possible approaches for } \\
\text { providing such support to end-users. }\end{array}$ & 4.2 & 0.9 & 40 \\
\hline
\end{tabular}


Table 1: continued

\begin{tabular}{|c|c|c|c|}
\hline Components/Objectives of the Curriculum & Mean & $\begin{array}{l}\text { Std } \\
\text { Dev }\end{array}$ & $\begin{array}{c}\mathbf{N} \\
\text { Value }\end{array}$ \\
\hline Demonstrate an understanding of different operating system platforms. & 4.1 & 0.8 & 39 \\
\hline $\begin{array}{l}\text { Demonstrate an understanding of operating system installation, administration, and } \\
\text { upgrading. }\end{array}$ & 4.1 & 1.0 & 39 \\
\hline Identify human factor issues associated with the use of OEIS technologies. & 4.1 & 0.8 & 39 \\
\hline $\begin{array}{l}\text { Explain how systems concepts can be applied to the planning, design, implementation, and } \\
\text { administration of end-user support systems. }\end{array}$ & 4.0 & 0.6 & 39 \\
\hline Manage, configure, and troubleshoot networked software connections. & 4.0 & 0.9 & 39 \\
\hline Assign users to groups and ensure adequate permissions on the network. & 4.0 & 0.9 & 39 \\
\hline Identify problems and formulate solutions related to telecommunications and networking. & 4.0 & 0.9 & 40 \\
\hline $\begin{array}{l}\text { Examine and use current methodologies for information systems security design, } \\
\text { implementation, and monitoring. }\end{array}$ & 4.0 & 0.8 & 38 \\
\hline Function as an entry-level facilitator and team leader in a collaborative technology setting. & 3.9 & 0.9 & 39 \\
\hline Create workplace design solutions to ensure worker comfort, safety, and productivity. & 3.9 & 1.1 & 40 \\
\hline $\begin{array}{l}\text { Demonstrate an understanding of the vocabularies and theories of telecommunications and } \\
\text { networking. }\end{array}$ & 3.9 & 1.0 & 40 \\
\hline Develop sufficient technical expertise to create informative Web pages. & 3.9 & 1.2 & 39 \\
\hline Identify and prescribe solutions for commonly occurring Helpdesk end-user problems. & 3.9 & 0.9 & 40 \\
\hline $\begin{array}{l}\text { Apply project management methodology and tools to the development of an OEIS systems } \\
\text { analysis and design project. }\end{array}$ & 3.9 & 0.9 & 40 \\
\hline Demonstrate effective use of online telecommunication applications and services. & 3.9 & 0.9 & 39 \\
\hline Discuss effective application of emerging communication technologies. & 3.9 & 1.0 & 40 \\
\hline Investigate key functional aspects of Web-based applications. & 3.8 & 1.1 & 39 \\
\hline Develop course delivery systems for end-user training. & 3.8 & 0.8 & 40 \\
\hline $\begin{array}{l}\text { Undertake review and benchmarking of information systems security practices, techniques, } \\
\text { and methods for securing and organization's information assets. }\end{array}$ & 3.8 & 0.8 & 39 \\
\hline $\begin{array}{l}\text { Justify the desirability of strategic planning and how OEIS solutions can drive organizational } \\
\text { goals. }\end{array}$ & 3.8 & 1.0 & 40 \\
\hline $\begin{array}{l}\text { Acquire the fundamentals of evolving Internet technologies and Web authoring using } \\
\text { currently popular Web editor tools. }\end{array}$ & 3.7 & 1.3 & 39 \\
\hline Understand the prevalent models for developing technical training materials. & 3.7 & 1.1 & 40 \\
\hline Recognize and apply appropriate Web design to meet user requirements. & 3.7 & 1.3 & 38 \\
\hline Evaluate the alternative solutions from both the end-user and technical perspectives. & 3.7 & 1.0 & 40 \\
\hline Recognize the value of virtual, collaborative, Web-based groupware tools. & 3.7 & 1.1 & 39 \\
\hline $\begin{array}{l}\text { Articulate the relationships among various end-user information systems both from business } \\
\text { and technical perspectives. }\end{array}$ & 3.7 & 0.9 & 40 \\
\hline $\begin{array}{l}\text { Consider and analyze the impact of information systems security on organizations and } \\
\text { society. }\end{array}$ & 3.7 & 1.1 & 39 \\
\hline Defend the selected OEIS solution in the context of real-world business problems. & 3.7 & 1.0 & 40 \\
\hline $\begin{array}{l}\text { Understand the principles of global and ethical consideration as related to end user } \\
\text { information systems. }\end{array}$ & 3.6 & 1.1 & 39 \\
\hline $\begin{array}{l}\text { Understand the context of Internet process within the overall functioning of global } \\
\text { organizations. }\end{array}$ & 3.6 & 0.9 & 39 \\
\hline $\begin{array}{l}\text { Practice knowledge management for effective organization and utilization of organizational } \\
\text { knowledge in terms of its properties, resources, strategies, and outcomes. }\end{array}$ & 3.6 & 1.0 & 39 \\
\hline Recommend learning and performance measures for the selected training type. & 3.5 & 0.9 & 40 \\
\hline Report and document OEIS activities via oral presentations and supporting multimedia. & 3.5 & 1.2 & 40 \\
\hline $\begin{array}{l}\text { Develop a systematic implementation and evaluation plan for Knowledge Management in a } \\
\text { realistic organizational environment. }\end{array}$ & 3.5 & 1.1 & 37 \\
\hline $\begin{array}{l}\text { Implement and use group decision support systems for managing knowledge in contemporary } \\
\text { organizations. }\end{array}$ & 3.4 & 0.9 & 39 \\
\hline Apply qualitative and quantitative methods of analysis through OEIS case studies. & 3.4 & 1.0 & 40 \\
\hline Write and evaluate reports generated through multiple Helpdesk reporting solutions. & 3.4 & 1.0 & 40 \\
\hline Evaluate alternative business models and strategies. & 3.3 & 0.9 & 38 \\
\hline Overall Alumni Assessment & 4.2 & 0.9 & 39 \\
\hline
\end{tabular}


The Web-based instrument required respondents to assess the importance of each of the objectives on a 5point Likert-type scale. To the question What is the level of importance of each of the following objectives of a curriculum specialization in Organizational \& End-User Information Systems (OEIS), respondents rated the level of importance for each objective on the following scale: $5=$ critical importance; $4=$ considerable importance; $3=$ some importance; 2 = little importance; and $1=$ no importance.

No effort was made to associate the objectives with individual courses in the model, given the topics are often covered at more advanced levels in a number of courses. Respondents also provided demographics regarding job titles, size of their organizations, and the nature of their respective organizations and provided other evaluations of the model with feedback regarding courses which have been helpful to them in the workplace.

\section{RESULTS OF THE ANALYSES}

Facilitate.com ${ }^{\mathrm{TM}}$ software, a group support system (GSS) that includes a survey utility, was used in the initial data gathering stage. Descriptive statistics were received through the web-based GSS and tabulated weekly. The analyses included the calculations of means, standard deviation, and number of respondents for the OEIS curriculum objectives. Table 1 contains these items and calculations, including the average response to the objectives as a whole.

A delimitation of this study is that the Likert scale of 5, 4, 3, 2, and 1 elicited a forced choice of no opinion was not included. The selected universities may also be viewed as delimitations. However, these universities are representative of those having OEIS undergraduate programs or specializations in this area. Additionally, at least one representative of each university was on the OEIS National Curriculum Task Force. Moreover, an adequate number of alumni from these institutions are currently engaged in IT-related positions.

For the analysis of the mean responses, a response in the range of 4.5-5.0 was interpreted to be an objective of critical importance; 3.5-4.49, of considerable importance; 2.5-3.49, of some importance; and 0.00-1.49, of no importance. The means ranged from a low mean of 3.3 to a high mean of 4.6. The overall assessment rating of 4.2 by alumni indicated that the respondents found the curriculum (as a whole) to be of considerable importance. The mean evaluations and the aggregate evaluation indicated, in general, the respondents found the objectives to be important for an end-user focused program in OEIS. The results of this study will further assist IT professionals as well as provide academicians with competencies needed by current IT students.

An understanding of the systems development life cycle (SDLC) and analysis and design side of an enduser support environment in combination with troubleshooting, i.e. helpdesk, project management, training program development, and using online telecommunications, were perceived by end-user computing alumni to be essential components of an effective end-user curriculum. This may be due to the variety of positions the graduates have obtained since graduation.

\section{FINDINGS AND CONCLUSIONS}

The demographic analysis showed the majority of graduates (70\%) have worked for their company two years or less. This could be explained by the fact that the more recent graduates of the respective institutions who were invited to participate in this study felt a stronger affiliation to their institutions and were, thus, more motivated to respond. Approximately 58\% are working in positions related to end-user computing and the overwhelming majority (85\%) are also working for companies with more than 25 employees. Less than half (40\%) were able to acquire full-time IT-related employment immediately upon graduation but are now employed in the area. Position titles ranged from systems analyst to end-user support specialist. Some titles noted included end-user in customer service, but approximately 12 of the 33 position titles clearly dealt with technology, troubleshooting, and/or analysis and support.

Participants rated six OEIS topics as the top components/objectives of the OEIS curriculum. Table 2 lists these items along with their mean, standard deviation and the number of respondents. 
Table 2: Alumni Ratings of Curriculum Objectives - Top Six List

\begin{tabular}{|c|c|c|c|}
\hline Components/Objectives of the Organizational \& End-User Information Systems Curriculum & Mean & $\begin{array}{l}\text { Std } \\
\text { Dev }\end{array}$ & $\begin{array}{c}\mathbf{N} \\
\text { Value }\end{array}$ \\
\hline $\begin{array}{l}\text { Demonstrate readiness for employment for an entry-level IT related position through } \\
\text { completion of an IT internship. }\end{array}$ & 4.6 & 1.0 & 40 \\
\hline Assess user needs and recommend computer solutions. & 4.4 & 0.6 & 40 \\
\hline Set up perform disk, directory, and file backups. & 4.4 & 0.9 & 39 \\
\hline Install, configure, upgrade, and maintain software. & 4.4 & 0.9 & 40 \\
\hline Demonstrate an understanding of software system maintenance and troubleshooting. & 4.3 & 0.9 & 39 \\
\hline $\begin{array}{l}\text { Understand and apply the concepts and theories underlying the administration of information } \\
\text { systems security. }\end{array}$ & 4.3 & 0.8 & 39 \\
\hline
\end{tabular}

Alumni rated these key components with a mean of 4.3 or higher. They include important curriculum aspects that would be integrated into courses, such as OEIS 7 (Internship), OEIS 2 (Computer User Support), and OEIS 3 (Planning, Design, Implementation, and Evaluation). These data further solidify the importance of an internship experience and reinforce an institution's decision to consider this as one of the most important components in an OEIS curriculum. Components/objectives of the curriculum that reached a mean of 4.0-4.2 are expanded upon in Table 3 below.

Table 3: Alumni Ratings of Curriculum Objectives - 4.2 - 4.0 Mean List

\begin{tabular}{|c|c|c|c|}
\hline Components/Objectives of the OEIS Curriculum & Mean & $\begin{array}{l}\text { Std } \\
\text { Dev }\end{array}$ & $\begin{array}{c}\mathbf{N} \\
\text { Value }\end{array}$ \\
\hline Implement, monitor, and troubleshoot basic information, network, and Web security systems. & 4.2 & 0.8 & 38 \\
\hline $\begin{array}{l}\text { Describe characteristics of end-user work environments and the impact of information } \\
\text { technology on work performance. }\end{array}$ & 4.2 & 0.9 & 40 \\
\hline Identify project objectives and end-user requirements. & 4.2 & 0.7 & 40 \\
\hline Design cost-effective technical training including new training and upgraded training. & 4.2 & 1.0 & 40 \\
\hline $\begin{array}{l}\text { Identify organizational and management issues related to the use of technology in the } \\
\text { workplace. }\end{array}$ & 4.2 & 1.0 & 40 \\
\hline Setup, install, configure and troubleshoot hardware. & 4.2 & 0.9 & 40 \\
\hline $\begin{array}{l}\text { Describe the concept of end-user technology support and differentiate possible approaches for } \\
\text { providing such support to end-users. }\end{array}$ & 4.2 & 0.9 & 40 \\
\hline Demonstrate an understanding of different operating system platforms. & 4.1 & 0.8 & 39 \\
\hline $\begin{array}{l}\text { Demonstrate an understanding of operating system installation, administration, and } \\
\text { upgrading. }\end{array}$ & 4.1 & 1.0 & 39 \\
\hline Identify human factor issues associated with the use of OEIS technologies. & 4.1 & 0.8 & 39 \\
\hline $\begin{array}{l}\text { Explain how systems concepts can be applied to the planning, design, implementation, and } \\
\text { administration of end-user support systems. }\end{array}$ & 4.0 & 0.6 & 39 \\
\hline Manage, configure, and troubleshoot networked software connections. & 4.0 & 0.9 & 39 \\
\hline Assign users to groups and ensure adequate permissions on the network. & 4.0 & 0.9 & 39 \\
\hline Identify problems and formulate solutions related to telecommunications and networking. & 4.0 & 0.9 & 40 \\
\hline $\begin{array}{l}\text { Examine and use current methodologies for information systems security design, } \\
\text { implementation, and monitoring. }\end{array}$ & 4.0 & 0.8 & 38 \\
\hline
\end{tabular}

A mean of 4.0 is a rating of considerable importance and 15 curriculum objectives are listed in the range of 4.0 to 4.2. An understanding of the systems development life cycle (SDLC) and analysis and design side of an enduser support environment in combination with troubleshooting, i.e. helpdesk, project management, training program development, and using online telecommunications, was perceived by end-user computing program alumni to be essential components of an effective end-user curriculum.

This may be due to the variety of positions that graduates obtained since graduation. Position titles ranged from systems analyst to end-user support specialist. Some titles noted included end-user in customer service, but approximately 12 of the 33 submitted position titles clearly dealt with technology, troubleshooting, and/or analysis and support, which would help to explain why alumni perceived the components listed in Tables 2 and 3 to be the most important components. 
Graduates also revealed which specific courses in their OEIS undergraduate programs had proven to be most valuable to them since gainful employment. The most common response was networking, followed by web design, database, hardware, and training fundamentals. Other items mentioned were technical writing, systems security, project management, more advanced database knowledge, ethics and global issues. When rating the overall program from which they received their degrees, $80 \%$ indicated that their degree was important. When asked to respond with additional courses that would be beneficial, alumni further noted that courses involving hands-on and experiential learning opportunities would be beneficial.

When comparing the OEIS model curriculum for information technology education, alumni identified topics of importance that match course content in the new model. A graphical depiction of the suggest core and electives is shown in Appendix A.

Graduates perceived the internship experience as being the most critical component of a curriculum with a mean of 4.6. This course (OEIS 7 - Internship) in the model is one of the seven (7) core courses. Additionally, OEIS 2 (Computer User Support), another core course in the model, covers software, troubleshooting, and file management skills identified by graduates with a mean of 4.3-4.4. User needs and recommended solutions are also covered in OEIS 2, thereby satisfying yet another of the perceived important topics (mean = 4.4). OEIS 4 (Technical Training \& Delivery Methods), which encompasses the design of cost-effective training solutions, also was identified as important with a mean of 4.2 .

Graduates also ranked the ability to explain how systems concepts can be applied to planning, design, implementation, and administration of end-user support systems as a high priority. The OEIS foundations course (Organizational \& End-User Information Systems) provides an introduction to many of these skills before students move into more in-depth courses. These skills are further covered in OEIS 3 (Planning, Design, Implementation, \& Evaluation). Other components designated important are included in OEIS 2 (Computer User Support), OEIS 3 (Planning, Design, Implementation, \& Evaluation), and OEIS 4 (Technical Training \& Delivery Methods).

The findings related to the value of coursework in the graduates' respective institutions reinforced the need for networking-OEIS 5 (Networking \& Telecommunications) in the curriculum. Additionally, web design, covered in OEIS 8 (eBusiness and Web Technologies) was identified as an important topic in the curriculum. Though considered an optional course in the OEIS model, OEIS 8 allows the flexibility for schools of higher education to include web design in the curriculum. OEIS 6 (Cases in IT) can also be designed to incorporate those areas deemed essential such as global and ethical issues. The optional courses allow programs to enhance student learning in collaborative learning technologies, network administration, information assurance, and other emerging topics such as virtualization. In summary, the graduates' perceptions of the model curriculum reinforced its effectiveness by identifying specific concepts that were of value to them as they work in an IT environment.

\section{RECOMMENDATIONS AND FURTHER RESEARCH}

Alumni of end-user information systems programs have noted the objectives established by the designers of the curriculum model are valued; consequently, academicians and/or curriculum designers could benefit from developing an information systems concentration or specialization around such objectives. Moreover, given the importance of these curriculum objectives, venues should be explored by universities for offering these courses in an online environment to promote more (and broader accessibility) to interested parties, especially if faculty resources are limited at smaller colleges/universities.

Educators whose programs do not include an internship experience should consider adding some type of experiential learning experience. This is essential in light of the current trend for institutions of higher learning to include service learning, as part of their core curricula. Experiential opportunities expand a student's knowledge beyond the scope of the technical aspects of an IT-related curriculum by providing students with real world applications. In rural areas, educators may wish to explore the plethora of opportunities related to completing a practicum in end-user technology support in their campus environments such as instructional technology and help desk administration. 
To supplement the findings of this study, further research to document the number of institutions following all or part of this IT curriculum is needed. Assessments of the extent to which individual programs are meeting curriculum objectives are also needed. It is recommended additional universities in a variety of regions across the United States survey their alumni to assess what specific IT objectives are currently needed, especially with the demand for enterprise systems, project management, health informatics, and virtualization skill sets.

The success rate of our alumni will continue to be determined by the extent to which these objectives are implemented and the willingness of faculty to update and revise IT education based upon trends in the global economy. With global competition and ubiquitous computer networks, organizations large and small of all types are turning to integrated, enterprise systems to more effectively manage the complexities of business operations. Consequently, all entry-level, business graduates would benefit greatly with more courses on business process integration and planning/implementation of information systems. Specifically, two core modules in this curriculum-Planning and Implementation as well as the Cases in Information Technology course--provide a valuable venue for introducing these essential skills. More research is essential regarding the perceived, key competencies and knowledge needed by those entering the global workplace of multinational enterprises that have implemented an enterprise system.

As IT-related jobs evolve and as new technologies and job titles emerge, a need exists to review and revamp model curricula to adapt to these rapid changes. Given the changes occurring in health information technology, virtualization, and technology management, the co-authors highly recommend that AIS-SIG OSRA curriculum or steering committees investigate venues for including these emerging areas of specialization in future curricular revisions.

Finally, as academicians who will educate and prepare IT students for computing careers, alumni remind us to remember the dynamic nature of this ever-changing global context in which they will become employed. As educators, we must help our students understand that technological developments represent not just artifacts, but forceful tools of change that can have both positive and negative impacts. In today's Internet world where social interface is unlimited, and where access to information is practically unlimited, we need to help our students explore "possible technological consequences both intended and unintended, for better or worse" (Smith, 2010, p. 23). Lastly, we need to further examine the interface of technology and society in terms of aiding our alumni in making informed ethical decisions, especially in the business information systems discipline, and as the digital revolution forges a new path of e-possibilities.

\section{AUTHOR INFORMATION}

C. Steven Hunt is Professor of Information Systems in the College of Business \& Public Affairs at Morehead State University. He chaired the 2004 National Organizational \& End-user Information Systems (OEIS) Curriculum Task Force. His research interests and publications focus upon enterprise systems, cloud computing, business process improvement, IS Curricula, and Health Informatics.

Tena B. Crews holds the rank of Professor of Integrated Information Technology at the University of South Carolina. Research interests include: Online learning design, development, assessment and online workload management strategies.

Susan Feather-Gannon is Professor of Information Technology in the Seidenberg School of Computer Science and Information Systems at Pace University. She served as president of the Organizational Systems Research Association when the National OEIS Curriculum Task Force began curriculum reengineering.

Darla Hunt is Chair of Business \& Information Technologies at Maysville Community \& Technical College where she teaches microcomputer applications and information technology. She has presented at numerous national and international conferences and has a recent publication in the Journal of Business \& Training Education.

Lola Smith is Instructor of Information Systems at Morehead State University, College of Business \& Public Affairs, and teaches microcomputer applications as well as Business \&Technical Presentations. She has numerous 
journal publications in the areas of communication, technology, and management such as the Human Systems Management Journal.

\section{REFERENCES}

1. Abu-Hamatteh, Z. S. H., \& Al-Jufout, S. A. (2003). Educational outcomes vs the world New industrial and economical demands: Jordanian electrical and mining sectors as a case study. Pakistan Journal of

Information and Technology 2(1), 78-82.

2. Ballenstedt, B. R. (2009, August 31). Competing for IT skills. Govexec.com [Online]. http://www.govexec.com/dailyfed/0809/083109ww.htm.

3. Bureau of Labor Statistics. (2008). Occupational outlook handbook: Tomorrow's jobs. Bureau of Labor Statistics. Available at: http://www.bls.gov/oco/oco2003.htm.

4. Bureau of Labor Statiscis. (2008). Occupational outlook handbook: Computer support specialists and systems administrators. Available at: http://www.bls.gov/oco/ocos268.htm\#outlook

5. Caputo, D. (2005). A profile of emerging and declining areas of business information technology competencies. The Review of Business Information Systems Journal, 9(3), 79-83.

6. Chabrow, E. (2008). Damn the economy! IT employment rises to new heights. CIO Insight. Available at: http://www.cioinsight.com/print_article2/0,1217,1=223035,00.asp.

7. $\quad$ Conger, S., Venkataraman, R., Hernandez, A., \& Probst, J.. (2009). Market potential for ITSM graduates: A survey. Information Systems Management, 26(2), 176. Retrieved September 16, 2009 from ABI/INFORM Research. (Document ID: 1722496861)

8. Crews, T. B. (2005). Comparison of OSRA educators and AITP industry personnel telecommunications course content lists. Organizational Systems Research Association Proceedings. Retrieved March 28, 2005, from http://www.osra.org/2005/crews.pdf.

9. Crews, T. B. (Winter 2004). Telecommunications course content: Input from information technology professionals. Journal of Information Systems Education, 15(4), 417-426.

10. Dwyer, C., \& Knapp, C. (Winter 2004). How useful is IS 2002? A case study applying the model curriculum. Journal of Information Systems Education, (15)4, 409-415.

11. Galletta, D. (2007). Field of dreams: If we rebuild it, will they come back? Academic Resource Center. Available at: http://www.academicresourcecenter.net/curriculum/FacetMain.aspx?FT=Author\& Alpha=G\&AuthorID=837\&ResultsTitle $=$ Galletta\%252C\%2520Dennis\&ShowResults=1.

12. Galup, S. D., Dattero, R., \& Quan, J. J. (2004). The demand for information technology knowledge and skills: an exploratory investigation, Journal of International Technology and Information Management, 3(4), 253-261.

13. Gordon, E. (2005). The 2010 meltdown: Solving the impending job crisis. Westport, CT. Greenwood Publishing Group.

14. Hoffman, T. (2008). 8 hottest skills for '08. Computerworld, Retrieved December 19, 2008 at http://www.networkworld.com/news/2008/010208-the-eight-hottest-skills-for.html

15. Hunt, C. S. (Ed.) (2004). Organizational \& end-user information systems curriculum model for undergraduate education in information technology. Morehead, KY: Organizational Systems Research Association.

16. Jackson, J. (September 8, 2009). Gov't agencies need more IT workers. Microsoft Certified Professional Magazine. [Online]. Available at: http://mcpmag.com/articles/2009/09/08/govt-agencies-need-more-itworkers.aspx.

17. Kaihla, P. (September 2003). The coming job boom. Business 2.0. Retrieved April 11, 2005, from http://www.business2.com/subscribers/articles/mag/print/0,1643,51816,00.html

18. Kantor, A. (2005). You've come a long way, baby, but today... I.T. is it. The Roanoke Times. Available at: www.roanoke.com/business/wb/wb/xp-39439.

19. Kao, J. (2007). Innovation nation. New York: Free Press.

20. Klawe, M. (2007). Changing the image of computer science. CRA. Available: www.cra.org/CRN/articles/nov07/ggc.html.

21. Kurtz, J. (2008). Women in computer science. The Triangle. Available: http://media.www.thetriangle.org/media/storage/paper689/news/2008/01/11/News/Women.In.Computer.Sc ience-3149758.shtml 
22. Miller, C. S. \& Dettori, L. (2008). Employers' perspectives on IT learning outcomes. Proceedings of the $9^{\text {th }}$ Association for Computing Machinery (ACM) SIGITE Conference on Information Technology Education, Cincinnati, OH. Retrieved on December 19, 2008 from http://delivery.acm.org/10.1145/1420000/1414612/p213miller.pdf?key $1=1414612 \&$ key2=9681479221\&coll=GUIDE\&dl=GUIDE\&CFID=15253952\&CFTOKEN $=22742675$

23. Murphy, C. (2007, July 18). U.S. tech employment hits its highest point in seven years. InformationWeek. Available: http://www.informationwee.com/story/showArticle.jhtml?articleID=201002045.

24. National Association of Colleges and Employers (NACE) (2007). Job outlook 2008. Bethlehem, PA: National Association of Colleges and Employers. Available: www.naceweb.org.

25. Plas, J. (2008). Workforce shortage is real, but solutions must be creative. Wisconsin Technology Review. Available at: http://wistechnology.com/article.php?id=4433.

26. Ragan, J. M. (2007). An implementation strategy for developing interdisciplinary professional skills within the accounting curriculum. Review of Business Information Systems, 11(4), 31.

27. Lee, C. K.. (2005). Analysis of skill requirements for systems analysts in fortune 500 organizations. Journal of Computer Information Systems. 45, (4). 84-90.

28. Rand Corporartion. (2008, June 12). U.S. still leads the world in science and technology; Nation benefits from foreign scientists, engineers. Rand Corporation. Available at: http://www.rand.org/news/press/2008/06/12/

29. Smith, L. B. (2010). Online culture: More than Facebook. Unpublished manuscript, Morehead State University Freshman Year Seminar. Morehead, KY.

30. Smith, L. B., Hunt, Steve, Berry R., \& Hunt, D. (2005). An integrated it curriculum model for advancing education in information technologies, learning, and performance. Information Technology, Learning, and Performance Journal, 23(3).

31. Snyder, J., Slauson, G. J., \& Carpenter, D. (2009). An action plan to increase IS enrollment based on recent survey evidence. Information Systems Education Journal, 7(65). Available at: http://isedj.org/7/65/

32. Sparrow, E. (2003). Successful IT outsourcing. Springer Publishing, New York, NY.

33. U. S. News. (2008, December 11). Best careers 2009: Computer systems analyst/architect/designer. U.S. News.com [Online]. http://www.usnews.com/money/careers/articles/2008/12/11/best-careers-2009computer-systems-analystarchitectdesigner.html

34. Xie, Z. \& Bahaudin G. M. (2008). Strategies For Information Systems Candidates And Job Seekers In The Twenty-First Century Workplace. Review Of Business Information Systems, 12(1), 14.

35. Yellen, R. E., (2005). A new look at learning for the organization. Journal of Organizational \& End User Computing, 17(2), i-iii.

36. Weller, C. E., \& Wheeler, H. (2008, March 10). Our nation's surprising technology trade deficit. Center for American Progress. Available at: http://www.americanprogress.org/issues/2008/03/high_tech_trade.html.

37. World Economic Forum. (2008). The global information technology report 2007-2008. World Economic Forum. Available at: http://www.weforum.org/en/initiatives/gcp/Global\%20Information\%20Technology\%20Report/index.htm

38. World Economic Forum (2009). The global competitiveness report 2008-2009. World Economic Forum. Available at: http://www.weforum.org/en/initiatives/gcp/Global\%20Competitiveness\%20Report/index.htm 


\section{APPENDIX A - GRAPHICAL DEPICTION OF OEIS MODEL CURRICULUM}

\section{ORGANIZATIONAL \& END-USER INFORMATION SYSTEMS CURRICULUM MODEL}

\section{Advancing Education in Information Technologies, Learning, and Performance}



Excerpt from Organizational Systems Research Association Undergraduate Model Curriculum in Information Technology Education, p. 9 (Hunt, 2004) 